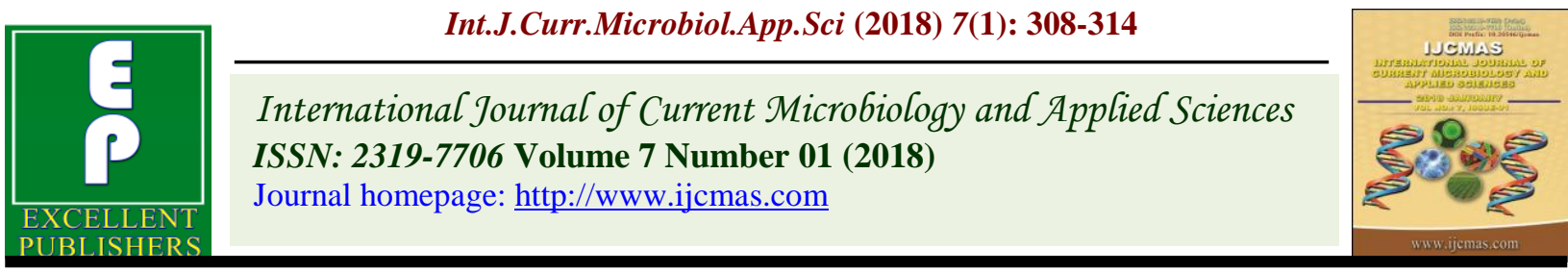

Review Article

https://doi.org/10.20546/ijcmas.2018.701.033

\title{
Need of Conservation Agriculture in India: Sustainability
}

\author{
Piyush Pradhan*, Ajay Verma and Mithlesh Kumar \\ Indira Gandhi Krishi Viswavidyalaya, Raipur, Chhattisgarh, 492012, India \\ *Corresponding author
}

\begin{abstract}
A B S T R A C T
\end{abstract}
\section{Keywords \\ Conservation agriculture, \\ Environment degradation, \\ Natural resources, Drudgery}

\section{Article Info}

Accepted:

04 December 2017

Available Online:

10 January 2018
Conservation agriculture is very important practice to reduce the cost of cultivation and natural resources of any crop. It was observed that 25-30\% cost taken in land preparation than other operation that can be reduced only by using high conservation tillage practice like adopting of zero tillage, minimum tillage, happy seeder, laser leveler etc. Continuing using of heavy machine and improper agricultural practices caused of soil degradation and impact on environment losses can be rectified by only conservation agriculture practices. Applied at the right time and on the right covering equipment could replace the use of, irrigation, pesticide, herbicides for crop establishment. The objective is to leave as many residues as possible in order to increase soil organic matter and to spread them as evenly as possible. Especially in environments where decomposition is fast and where the amount of residues is low it is not recommended to chop the residues. Rotavator is important machine which break the soil and crop residues and mix so that eventually. Conservation agriculture crop can be increased climatic resilence, food security, soil nutrion, energy reduction and income. Presently farmers are facing the problem of labour shortage and drudgery of farming these are all can be reduced by conservation tillage practice.

\section{Introduction}

The concept of conservation agriculture is relatively using of new and modern cultivation practices. Conventional agricultural practices promotes the extensive soil tillage, burning of crop residues and external inputs Such practices lead to soil degradation through loss of organic matter, soil erosion and compaction. In India more than $70-75 \%$ farmers are small land holding farmer they are still using traditional farm practices and are major contributor in total food production. Yet, for many, farming is a struggle often with only rudimentary tools and implements available. Most of the farmers have little attention to the longer term management of natural resources and can rarely afford input such as quality of seeds, fertilizer, heavy machines, and herbicides for chemical weed management. Conservation agriculture is to (i) achieve acceptable profits, (ii) high and sustained production levels, and (iii) conserve the environment (FAO, 2009). It further argues that conservation agriculture is based on enhancing natural biological processes above and below the soil surface. These go beyond zero-tillage and provide a range of technology and management options. Conservation agriculture practices are 
applicable to virtually all the crops, including cereals, horticulture and plantation crops. However, these are more popular in maize, soybean, rice and wheat. The conservation agriculture practices promises tremendous potential for different soils and agroecological systems.

These are neutral to size of holdings but their adoption is most urgently required by smallholder farmers to reduce their cost of production, increase profit, and save resources (Derpsch, 2008). The scarcest input to smallholder farming is often energy, particularly the human energy or farm power that is required for land preparation, crop establishment, weeding, harvesting and transport. Many smallholder farmers are women and youth who carry the major burden of arduous hand labour and is a main reason why rural youth in developing regions migrate to urban areas in search of an alternative to rural smallholder agriculture. Conservation agriculture is practice to reduce and eliminating the need for land preparation for crop production.

Applying precision agriculture would be increase the efficiency of sowing, irrigation, spraying, harvesting and threshing, by latest technology for crop production. Crop is totally dependent on soil quality in terms of its hardness, fertility. The capacity of a specific kind of soil to function, within natural or managed boundaries, to sustain plant and animal productivity, maintain or enhance air and water quality and support human health and habitation''(Karlen et al., 1997).

The soil's ability to function as a component of an ecosystem may be degraded, aggraded or sustained as used dependent properties change in response to landuse and management. Therefore to achieve higher production there should must focus on conservation tillage practices.

\section{Environmental benefits of conservation tillage}

Reduced soil erosion, improvement in soil moisture, increase beneficial soil microbes, less fuel consumption Reduce soil compaction, reduced dust and smoke to pollute air, maintain of soil nutrient and fertility.

\section{Conservation Tillage}

Rice wheat cropping system is oldest and most prevalent agricultural practices of India. Rice occupies $153 \mathrm{~m}$ ha land throughout the world. In India out of $43 \mathrm{~m}$ ha area under rice is cultivated in $24 \mathrm{~m}$ hac about $56 \%$ of the area (Anonymous, 2005) this involves ploughing, when the soil is wet, puddling it and keeping the flooded area for the duration of rice crop. A wetland soil rice practice thus destroys the soil structure and creates a poor physical condition for the following wheat crop. This soil condition can reduce wheat yield (Sur et al., 1981; Boparai et al., 1992) presumably by limiting root growth and distribution (Oussible et al., 1992). For regeneration and maintenance of soil structure within this cropping system, plant residues are very important (Verma and Bhagat, 1992), but for various reason, the amount of residue being returned to the soil is not adequate. Rice grown with conservation tillage can produce yields similar to that under conventional puddling with minimized expenses on field preparations (Sharma and De Datta, 1986). The conservation tillage system is an ecological approach to soil surface management and seedbed preparation. It minimizes soil erosion risks, conserves soil water, decreases fluctuations in soil temperature of the surface layer, improves soil organic carbon content, and enhances soil structure. Implemented as a science-based technique, conversion from conventional to conservational tillage system may increase 
soil organic carbon, improve soil structure, and enhance soil quality and its environmental regulatory capacity. Also, crop residue is an important and a renewable resource. Developing techniques for effective utilization of this vast resource is a major challenge. Improper use of crop residues (e.g. removal, burning or plowing under) can accelerate erosion, deplete soil fertility, and pollute environment through burning and eutrophication of surface and contamination of groundwater.

Residue management may save energy, recycle nutrients, enhance soil fertility, improve soil structure, sequester carbon, and mitigate the greenhouse effect. The effect of conservation tillage on soil properties can be illustrated briefly as below: 1. Improved pore size distribution and better aggregation this can be obtained by the adoption of zero tillage. Thus, zero tillage plays an important role in improving soil structure and soil aggregation. 2. Surface residues maintained under zero tillage system moderate moisture fluctuations and thus reduce both evaporation and runoff and also increase the infiltration by reducing surface sealing and decreasing runoff velocity.

3. Contrasting effects of soil management experiments in bulk density are common. They are mostly related to management factors such as planting machinery (machine weight, tire width, inflation pressure), number of machine passes, as well as the soil water content at which the soil is tilled. 4 . Contrasting results are available in the literature regarding soil hydraulic conductivity and infiltration. 5. Conversion from conventional to zero tillage, reduced erosion and avoided surface sealing because of crop residue cover on the surface and higher aggregate stability under zero tillage conditions. 6. Soil temperature is modified by the crop residue.

\section{Soil moisture content}

Zero tillage increase the $28 \%$ soil water at plant as compared to conventional tillage and an associated increase of $1.2 \mathrm{t} / \mathrm{ha} /$ year wheat grain (McGarry et al., 2000). More plant residues were left on or near the soil surface no tillage which led to lower evapotranspiration and higher content of soil water in the upper $(0-10 \mathrm{~cm})$ soil layer (Rasmussen, 1999). The plant available water content was significantly higher with zero than conventional tillage in rice-wheat cropping system (Bhattacharyya et al., 2006b and Bhattacharyya et al., 2008). Surface residues maintained under zero tillage system moderate moisture fluctuations and thus reduce both evaporation and runoff (Blevins and Frye, 1993).However, different types and extent of tillage did not have any major influence on the moisture content at harvest, although it was high at the time of initial tillage and reduced with subsequent tillage operations (Srivastava et al., 2000). It has been well established that increasing amounts of crop residues on the soil surface reduce the evaporation rate (Gill and Jalota, 1996; Prihar et al., 1996). Residue mulch or partial incorporation in soil by conservation tillage has also been shown to increase the infiltration by reducing surface sealing and decreasing runoff velocity (Box et al., 1996).

\section{Soil degradation}

CA provides the context in terms of relevant cultivation methods, its ecological and technical feasibility (rainfall, soils), its beneficial results (water saving, maintenance of resource base) and its economic impact input saving and increased outputs. CA gives the detailed information of approaches, methodologies and interactions. Soil degradation due to erosion and compaction processes is the most serious environmental problem caused by conventional agriculture. 
Estimates reveal that an annual loss of 75 billion tonnes of soil translates into US\$ 400 billion per year; about US\$ 70 per person per year (Vlek, 2008). About 10 million hectares of good quality land is lost annually for agricultural uses, due to soil degradation processes, which adversely affect agricultural production and profitability. Degradation of natural resources is adversely influencing livelihood opportunities of poor and dragging them to poverty trap. A study by the Food and Agriculture Organization of United Nations (FAO) revealed that an estimated 1.5 billion people depend directly on land that is degrading. Another study by the FAO indicated that land degradation is worsening rather than improving, with declining trends revealed across some 24 per cent of global land area. According to this study, the main driver of degradation is poor land management (Paroda, 2009). The high population growth rate, the degradation of agricultural lands and the scarcity of water, in continuous dropping of rainfall have raised some doubt about the continuous suitability of the dominant agricultural system in India. In face of these environmental and economic challenges there is a need to reconsider those classical agricultural systems and try to adopt agricultural system and technology which may prevent soil degradation and fertility, energy conservation.

Conservation agriculture is a promising solution for future productive agriculture in rainfed as well as dry land, and irrigated agriculture by no tillage, minimum tillage, and mulch tillage for direct drilling or seeding but looked upon sceptically because of lack of information between farmers. Conservation agriculture (CA) is considered a promising solution for the region, but looked upon skeptically because of lack of information and because of the varying definitions and terms used (no-tillage, direct planting through a soil cover, conservation tillage, etc.). The system risks not to be accepted by farmers, if the (economical) benefits are not superior to those of the conventional systems, and if it is not supported by agricultural policies and scientific research. Great efforts by all farmers, researcher, scientist and stakeholders are required to implement this system which remains a real hope for sustainable agriculture in India in rainfed as well as in irrigated agriculture (no-tillage, direct drilling/seeding, drilling/seeding through a vegetative cover). Establishing a well-managed system of conservation agriculture allows producers to increase and maintain soil organic matter and soil life. As such, the impact on soil stability, reduction of erosion, and increased water useefficiency are remarkable (Blanchart et al., 2000).Soil does not only impact on production, but has also an influence on the management of other natural resources, such as water. Soil structure is strongly correlated to the organic matter content and to the soil life.

Organic matter stabilizes soil aggregates, provides feed to soil life and acts as a sponge for soil water. With intensive tillage based agriculture, the organic matter of soil is steadily decreasing, leading first to a decline in productivity, later to the visible signs of degradation and finally to desertification (Shaxson and Barber, 2003). The lack of yield response to high fertilizer dose in the Indo Gangetic Plains can be attributed to deteriorated soil health as a result of overexploitation (Aulakh, 2005). In the Indian states of Uttaranchal or Haryana the organic carbon content in soils reaches minimum values below $0.1 \%$ (PDCSR, 2005). Agricultural production has all over the world led to soil degradation, more pronounced in tropical regions, but also in moderate climatic zones. The world map of degraded soils indicates that nearly all agricultural lands show some levels of soil degradation (FAO, 2000). 
Table 1. Energy consumption in tillage operation on bullock farms

\begin{tabular}{|c|c|c|c|c|}
\hline \multirow[t]{2}{*}{ Crop } & \multirow[t]{2}{*}{ Parameter } & \multicolumn{2}{|c|}{ Tillage Treatment } & \multirow{2}{*}{$\begin{array}{l}\text { Per cent saving over } \\
\text { traditional method }\end{array}$} \\
\hline & & $\begin{array}{l}\text { Bullock-drawn moldboard } \\
\& \text { soil stirring plough }\end{array}$ & $\begin{array}{l}\text { Bullock-drawn disc } \\
\text { harrow-cum-puddler }\end{array}$ & \\
\hline \multirow[t]{3}{*}{ Paddy } & Labour, h/ha & 49.4 & 23.5 & 52.4 \\
\hline & Pair of bullocks, h/ha & 49.4 & 23.5 & 52.4 \\
\hline & Energy in tillage, MJ/ha & 611 & 328 & 46.3 \\
\hline \multirow[t]{3}{*}{ Wheat } & Labour, h/ha & 54.5 & 25.6 & 53.0 \\
\hline & Pair of bullocks, $\mathrm{h} / \mathrm{ha}$ & 54.5 & 25.6 & 53.0 \\
\hline & Energy in tillage, MJ/ha & 692 & 362 & 47.7 \\
\hline
\end{tabular}

Source: Singh et al, 1999

Table 2. Energy use in tillage on tractor farm

\begin{tabular}{|c|c|c|c|c|}
\hline \multirow[t]{2}{*}{ Crop } & \multirow[t]{2}{*}{ Parameter } & \multicolumn{2}{|c|}{ Tillage Treatment } & \multirow{2}{*}{$\begin{array}{l}\text { Per cent saving over } \\
\text { traditional method }\end{array}$} \\
\hline & & $\begin{array}{l}\text { Tractor-drawn disc } \\
\text { harrow \& cultivator }\end{array}$ & $\begin{array}{c}\text { Tractor-drawn } \\
\text { rotavator }\end{array}$ & \\
\hline \multirow[t]{4}{*}{ Paddy } & Labour, h/ha & 11.7 & 8.6 & 26.5 \\
\hline & Tractor, h/ha & 11.7 & 8.6 & 26.5 \\
\hline & Energy in tillage, MJ/ha & 3275 & 3106 & 5.2 \\
\hline & Diesel, lha & 54.2 & 51.6 & 4.8 \\
\hline \multirow[t]{4}{*}{ Wheat } & Labour, h/ha & 15.4 & 8.2 & 46.7 \\
\hline & Tractor, h/ha & 15.4 & 8.2 & 46.7 \\
\hline & Energy in tillage, MJ/ha & 3828 & 2586 & 324 \\
\hline & Diesel, l/ha & 62.5 & 42.6 & 31.8 \\
\hline
\end{tabular}

Source: Singh et al, 1999

\section{Benefits of conservation agriculture}

In India, Erenstein and Pandey (2006) studies to quantify the benefits of conservation agriculture in the Indo-Gangetic plain. Some of the benefits are given as below-

Yield advantage of zero tillage to rice and wheat by 10-17 per cent over conventional tillage.

Cost reduction by about Rs. 5760 per hectare (roughly by 5 to 10 per cent); ranging from Rs. 3055 to Rs. 8500 per hectare in different soils and eco-regions.

Water saving by $20-35$ per cent, and energy saving, especially of tractor time saved by 6090 per cent.

Projected saving of 1 million barrel of oil if the zero-tillage practice is adopted in about 3.5 million hectare area of Indo-Gangetic plain. High internal rate of returns (57 percent) assuming 33 per cent adoption of conservation agriculture in Indian part of Indo-Gangetic plain.

\section{Animal-drawn tillage implements}

Traditionally, soil stirring and mould board ploughs are used by farmers having animals as power source. The field capacity of the traditional implements is about $0.3-0.4$ ha/day and thus work output is low. Animal-drawn disc harrows are also used for land preparation. These harrows have either four or six discs depending upon the size of draft animal available. For puddling in the rice fields, the design of disc harrow was further modified and a drum was introduced in between two discs instead of spool and known as harrow puddler. The drum limits sinkage of the discs up to 125 $\mathrm{mm}$ during puddling operation and thus even medium sized draught animals can pull the implement. During dry seedbed operation, the drums simultaneously break soil clods and consequently reduce the number of tillage operations. These functional advantages make the implement energy-efficient. Comparison of energy required in tillage operation using traditional animal drawn implement vis-à-vis animal drawn disc harrow-cum-puddler is indicated in Table 1. Energy required in tillage operation ranged between $328-362 \mathrm{MJ} / \mathrm{ha}$ by 
bullock-drawn disc harrow-cum-puddler for paddy and wheat crops and was about 46 to 48 per cent less than traditional implements.

\section{Tractor-drawn tillage implements}

Tractor-drawn type cultivator was widely used by the farmers for seedbed preparation and intercultural operations. Farmers prefer to give one or two passes of disc harrow to cut the crop residue and bury them into the soil before presowing irrigation. Introduction of the above mentioned implements slowly replaced use of animal operated implements. Tractor drawn cultivator is the common tillage implement for dry and wet seedbed preparation, it can be seen that in India most of the tractor owner have the cultivator for seedbed preparation Farmers prefer to use offset-disc harrow after harvesting of paddy and wheat, particularly after harvesting by combine. More and more areas are coming under combine harvest. Seedbed preparation for kharif and rabi crops is becoming time consuming and consequently sowing is delayed. To reduce the number of tillage operations, save time and energy, tractordrawn rotavator has been introduced. The use of rotavator in lieu of disc harrow for seed bed preparation saves 30-35 per cent of energy in heavier soils. Results of studies conducted on energy used in tillage for paddy and wheat crop using conventional implements (tractor-drawn disc harrow, and cultivator and improved equipment (rotavator) is indicated in Table 2. For paddy, use of rotavator required 5 per cent lower energy and 26.5 per cent less time than the conventional implement.

Conservation agriculture technologies are the future of sustainable agriculture. There are potential benefits of conservation agriculture across different agro-eco-regions and farmers groups. The benefits range from nano-level (improving soil properties) to micro-level (saving inputs, reducing cost of production, increasing farm income), and macro-level by reducing poverty, improving food security, alleviating global warming. There is a need for a global movement for promoting conservation agriculture. In India, the concept of conservation agriculture may be integrated with various government programs by sensitizing policy advisors, professionals and financial institutions. The benefits of conservation agriculture need to be effectively communicated to all the stakeholders for its widespread adoption by the farming community. Failing that the sustainability of agriculture would be under threat and adversely affect natural resources and agricultural production. The most affected would be the under privileged and poor farmers in unfavorable and marginal areas. So it can be concluded that conservation agriculture is most need for Indian agricultural land for longer utilization and effective crop production.

\section{References}

Anonymous, 2005. Atlas of Rice and World. Rice Statistics.

Bhattacharyya, R., Kundu, S., Pandey, S.C., Singh, K.P., and Gupta, H.S. 2008. Tillage and irrigation effects on crop yields and soil properties under the ricewheat system in the Indian Himalayas. Agric. water management, 95: 993-1002.

Bhattacharyya, R., Singh, R. D., Chandra, S., Kundu. S., and Gupta, H.S. 2006b. Effect of tillage and irrigation on yield and soil properties under rice(Oryza sativa), wheat (Triticum aestivum) system on a sandy clay loam soil of Uttaranchal. Indian J. Agr. Sci., 76 (7): 405-409.

Blanchart, E., Achouak, Albrecht, A., Barakat, M., Bellier, G., Cabidoche, Y. M., Hartmann, C., Heulin, T., Larre-Larroy, C., Laurent, J.-Y., Mathieu, M., Thomas, F., Villemin, G., Watteau, F., 2000. Determinants biologiquesdansles vertisols despetites Antilles conséquencessurl'érodibilité, Etude etgestion des sols, 7, 4, numéro special. 309-328.

Blevins, R. L. and Frye, W.F. 1993. Conservation tillage: an ecological approach to soil management, Adv.Agron., 51: 34-77. 
Boparai, B. S., Singh, Y., Sharma, B.D. 1992. Effect of green manuring with Sesbania aculeate on physical properties of soil and on growth of wheat in rice-wheat and maize-wheat, cropping systems in a semiarid regions of India. Arid Soil Res., Rehab. 6: 135-143.

Box, J.E., Bruce, R.R., and Agassi, M. 1996. The effect of surface cover on infiltration and soil erosion. In Soil Erosion Conservation and Rehabilitation. 107- 123.

Derpsch, R. 2008. "No-Tillage and Conservation Agriculture: A Progress Report" No-till Farming Systems. Special Publication No. 3.World Association of Soil and Water Conservation, Bangkok.

Erenstein, O. and Pandey V. L. 2006. Impact of Zero-Tillage Technology, CIMMYT, Mexico.

Food and Agriculture Organization of the United Nations (FAO). 2009. Conservation Agriculture. Rome, Italy.

Gill, B.S. and Jalota, S.K. 1996. Evaporation from soil in relation to residue rate, mixing depth, soil texture and evaporativity. Soil Technol., 8: 293-301.

Karlen, D.L., Mausbach, M.J., Doran, J.W. and Cline, R.G. 1997. Soil quality: a concept, definition, and framework for evaluation. Soil Sci. Soc. Am. J.,61: 4-10.

Mc Garry, D., Bridge, B.J. and Radford, B.J. 2000. Contrasting soil physical properties after zero and traditional tillage of an alluvial soil in the semi-arid subtropics. Soil Till. Res., 53:105-115.

Oussible, M., Crookstan, R.K. and Larson, W. E. 1992. Subsurface compaction reduced root and shoot growth and grain yield of wheat. Agron. J., 84: 34-38.
Paroda, R. S. 2009. Global Conventions and Partnerships and their Relevance to Conservation Agriculture in $4^{\text {th }}$ World Congress on Conservation Agriculture in New Delhi, National Academy of Agricultural Sciences, 30-35.

Prihar, S.S., Jalota, S.K. and Steiner, J. L. 1996. Residue management for reducing evaporation in relation to soil type and evaporativity. Soil Use Manag.,12: 150157.

Rasmussen, K.J. 1999. Impact of ploughless soil tillage on yield and soil quality: A Scandinavian review. Soil Till. Res., 53: 3-14.

Sharma, P.K. and De Datta, S.K. 1986. Physical properties and processes of puddled rice soils. Adv. Soil Sci., 5: 139-178.

Singh S., Dipanker D., and Pannu C. J. S 1999. Energy Conservation Technology for farm Operations in Punjab. Technical Bulletin no. CIAE/99/73.

Srivastava, A.P., Panwar, J.S. and Garg, R. N. 2000. Influence of tillage on soil properties and wheat productivity in rice (Oryza sativa), wheat (Triticum aestivum) cropping system. Indian J. Agric. Sci., 70 (4): 207-210.

Sur, H.S., Prihar, S.S., Jalota, S.K. 1981. Effect of rice-wheat and maize-wheat rotations on water transmission and wheat root development in a sandy loam soil of Punjab, India. Soil Till. Res., 1: 361-371.

Verma, T. S. and Bhagat, R.M. 1992. Impact of rice straw management practices on yield, nitrogen uptake and soil properties in a rice-wheat rotation in northern India. Fertil. Res., 33: 97-106.

Vliek, Paul L. G. 2008. The Incipient Threat of Land Degradation Journal of Indian Society of Soil Science, 56.

\section{How to cite this article:}

Piyush Pradhan, Ajay Verma and Mithlesh Kumar. 2018. Need of Conservation Agriculture in India: Sustainability. Int.J.Curr.Microbiol.App.Sci. 7(01): 308-314.

doi: https://doi.org/10.20546/ijcmas.2018.701.033 